\title{
Exploring Phyllosphere Bacteria for Growth Promotion and Yield of Potato (Solanum tuberosum L.)
}

\author{
Satish Kumar ${ }^{1}$, Deepika Chaudhary ${ }^{1}$, Rashmi ${ }^{1}$, Raman Jangra ${ }^{1}$, \\ Anju Kumari ${ }^{2}$ and Rakesh Kumar ${ }^{*}$ \\ ${ }^{1}$ Department of Microbiology, CCS Haryana Agriculture University, Hisar 125004, \\ Haryana, India \\ ${ }^{2}$ Centre of Food Science and Technology, CCS Haryana Agriculture University, Hisar \\ 125004, Haryana, India \\ *Corresponding author
}

\begin{abstract}
A B S T R A C T

\begin{tabular}{|l|}
\hline Ke y w or d s \\
$\begin{array}{l}\text { Potato (Solanum } \\
\text { tuberosum } \mathrm{L} .) \\
\text { Phyllosphere } \\
\text { bacteria }\end{array}$ \\
\hline Article Info \\
\hline $\begin{array}{l}\text { Accepted: } \\
10 \text { March } 2018 \\
\text { Available Online: } \\
10 \text { April } 2018\end{array}$ \\
\hline \hline
\end{tabular}

Plant growth promoting bacteria (PGPB) are plant associated micro-organisms known to induce plant defences and confer beneficial effects such as increased plant growth and low susceptibility to diseases caused by pathogens. Plant growth promoting bacteria are capable of significantly altering the growth phenotype of inoculated plants. Plants inoculated with PGPBs are capable to assimilate minerals and synthesize plant hormones. A total of 46 bacteria isolates were obtained from phyllosphere of different crops (Wheat, Pearl millet, Cotton, Mungbean and Potato). All the bacterial isolates were characterized for various plant growth promoting traits i.e., $\mathrm{NH}_{3}$ excretion, IAA production, Psolublization and Nitrate reductase. Seven isolates (POK-3, WHN-2, WHN-1, PMK-3, WHK-2, COJ-4, and MUK-1) were applied as foliar spray in different treatments. The plants inoculated with the phyllospheric bacterial isolates recorded an improved plant growth in terms of plant height and potato yield. Therefore, it can be concluded that application of PGPB has immense potential to be used as agricultural crop inoculants as they promote plant growth as well as improve the health and yield of the plants.
\end{abstract}

\section{Introduction}

Potato is an economical food, which belongs to genus Solanum (family Solanaceae) that consists of about 2,000 species and it provides a source of low cost energy to human diet. For vegetable purposes, potato has now become one of the most popular crops in India and cultivated in almost all states and under very diverse agro climate conditions. The states of Uttar Pradesh, West Bengal, Punjab, Bihar and Gujarat accounted for more than 80 per cent share in total production. At world level, China, India, Russian Federation, USA, Ukraine, Germany and Poland shared more than 62 per cent of total global production potato. India ranks second, next to China in global production of potato (Anonymous, 2016). Plant-associated bacteria colonize the rhizosphere (rhizobacteria), the phyllosphere (epiphytes) and inside of plant tissues (endophytes). Phyllosphere bacteria can 
promote plant growth and both suppress or stimulate the colonization and infection of tissues by plant pathogens (Lindow and Brandl, 2003). Phyllosphere microbiology has much to offer to the field of microbial ecology and promises to contribute the more effective and less environmentally damaging means of plant protection. Indole acetic acid (IAA) is one of the most physiologically active auxins. IAA is a common product of L-tryptophan metabolism by several microorganisms. Also, indole-3-acetic acid (IAA), the major naturally occurring auxin, is a signalling molecule in microorganisms because IAA affects gene expression in some microorganisms (Spaepen and Vanderleyden, 2016). They can also be involved in plant protection, which is due to direct interactions of microorganisms through the production of antibiotic compounds and competition for resources (Berg, 2009). Nitrogen is one of the most important nutrients required for plant growth and productivity as it forms an integral part of proteins, nucleic acids and other essential bimolecular (Bockman, 1997). Biological nitrogen fixation involves the conversion of nitrogen to ammonia by microorganism using a complex enzyme system identified as nitrogenase (Kim and Rees, 1994). Biological nitrogen fixation fixes about $60 \%$ of the earth's available nitrogen and represents an economically beneficial and environmentally sound alternative to chemical fertilizers (Ladha and Kundu, 1997). Plant growthpromoting rhizobacteria that fix nitrogen in non-leguminous plants are diazotrophs that form a non-obligate interaction with the host (Glick et al., 1999). Phosphorus plays an indispensable biochemical role in photosynthesis, respiration, energy storage and transfer, cell division, cell enlargement and several other processes in the living plant. Phosphate solubilizing microorganisms are known to improve solubilization of fixed soil phosphorus and applied phosphates resulting in higher crop yields. Phosphate solubilizing bacteria are a low cost solution that gives a thrust to economic development without disturbing ecological balance. Bio fertilizers are the substances that involve living microorganisms which are when applied to seed, plant and soil surfaces, colonizes the rhizosphere or the interior of the plant and then help to promote plant growth by increasing the supply or availability of nutrients to them (Vessey, 2003). Bio fertilizers add nutrients to the plants through the natural processes of biological nitrogen fixation, phosphorus solubilization, and synthesizing of growth-promoting substances. These biofertilizers can be used to reduce the use of chemical fertilizers and pesticides. So, the internal and external foliar microbiota and their likely key roles in plant performance, growth and health, currant studies to understand better plant functioning and its responses and effects in a changing world, the importance and role of bacteria in phyllosphere making it available to the plants.

\section{Materials and Methods}

\section{Isolation of bacteria from the phyllosphere of different crops}

Bacteria were isolated from the phyllosphere of different crops (Wheat, Potato, Cotton, Mung bean and Pearl millet) grown at CCS HAU research farm by using serial dilutions method.

\section{Plant growth promoting traits}

Quantitative estimation of the indole acetic acid (IAA) was carried out by inoculating $1 \mathrm{ml}$ of the respective bacterial suspension in $10 \mathrm{ml}$ respective broth containing L-tryptophan (100 $\mu \mathrm{gml}^{-1}$ ), and incubating it in the dark for $96 \mathrm{~h}$. The concentration of IAA in the culture supernatant was estimated by the procedure of Salkowski s method (Glickmann and Dessaux, 1995). All the isolates were tested for their 
ability to excrete ammonia by growing the cultures in $30 \mathrm{ml}$ respective broths. Ammonia released in the supernatant was determined according to the method of Chaney and Marbach (1962). Phosphorus solubilization were tested on Pikovskaya's agar plates. Five $\mu l$ of each culture broth was taken and spotted on these plates. These plates were incubated at $28 \pm 2{ }^{0} \mathrm{C}$ for 4 days in a BOD incubator and observed for P-solubilization zone. Zone of solubilization and colony diameter were measured. Solubilization index was calculated using the following formula:

Solubilization index $=(0.5 \mathrm{H})^{2} /(0.5 \mathrm{~A})^{2}$

$\mathrm{A}=$ Colony diameter

$\mathrm{H}=$ Diameter $($ Colony + Halo zone $)$

Nitrate Reductase activity in bacterial isolates was determined by the method given by MacFaddin (1980). All isolates were inoculated in $30 \mathrm{ml}$ nitrate broth and were incubated at $30^{\circ} \mathrm{C}$ for 8 days under stationary conditions of growth. Colour intensity was estimated at $540 \mathrm{~nm}$ using UV-vis spectrophotometer against a reagent blank within 5-10 seconds, after adding second reagent.

\section{Selection of bacterial isolates for pot house studies in potato crop}

On the basis of plant growth promoting traits, seven bacterial isolates were selected for the pot house studies. Isolate PMK3 (from Pearl millet phyllosphere) showed highest ammonia excretion along with all other traits, WHK2 showed maximum IAA production, COJ4 was showing highest phosphate solubilization and POK3, MUK1 and WHN2 showed all traits positively (Table 1).

\section{Effect of foliar spray on growth of potato}

Nine kg sandy loam soil was used to fill up the plastic pots. Seeds of potato crop (Solanum tuberosum L.) var. Kufri bahar were sown in pots. After 20 days of sowing, foliar spray of selected bacterial isolates and Azotobacter chroococcum Mac27 were done according to the treatments. Plants were uprooted after 90 days of crop and observations on plant height and potato yield were recorded.

\section{Statistical analysis}

The experimental data were analysed using OPSTAT software available on university home page.

\section{Results and Discussion}

A total of 46 bacterial isolates were retrieved from five phyllospheric leaf samples (wheat, potato, cotton, pearl millet and mung bean) using dilution plating on Nutrient agar media, King's B media and Jensen's $\mathrm{N}_{2}$ free media. Bacterial isolates were characterized for ammonia excretion.

All the 46 isolates were capable of excreting ammonia under shaking conditions ranging from $0.86-5.29 \mu \mathrm{g} / \mathrm{ml}$. Maximum ammonia excretion was showed by PMK3 $(5.29 \mu \mathrm{g} / \mathrm{ml})$ followed by WHN2 (Table 1). Ammonia is the immediate product of nitrogen fixation in nitrogen fixing micro-organisms. Narula et al., (1981) and Chandna (1982) reported that wild strains of $A$. chroococcum are able to release ammonia in medium containing $1 \%$ sucrose as a carbon source. Lakshaminarayana et al., (2000) reported that diazotroph like Azotobacter had good capability of conversion of nitrogen to ammonia. Banik et al., (2016) reported that thirty-five isolates from four rice genotype possessed the intrinsic PGP traits like indole $(0.44-7.4 \mathrm{mg} / \mathrm{ml})$, ammonia (0.18-6 $\mathrm{mmol} / \mathrm{ml})$, nitrite $(0.01-3.4 \mathrm{~mol} / \mathrm{ml})$ and siderophore $(0.16-0.57 \mathrm{mmol} / \mathrm{ml})$ production. Inoculation of rice (cv. Swarna) seedling with selected isolates had a positive impact on plant growth. 
Table.1 Plant growth promoting traits of bacterial isolate selected for pot house studies

\begin{tabular}{|c|c|c|c|c|}
\hline $\begin{array}{c}\text { Isolate } \\
\text { no. }\end{array}$ & $\begin{array}{c}\mathrm{NH}_{3} \\
\text { excretion } \\
\left(\mu \mathrm{g} \mathrm{ml} \mathbf{l}^{-1}\right)\end{array}$ & $\begin{array}{c}\text { IAA } \\
\text { production } \\
\left(\mu g \mathrm{l}^{-1}\right)\end{array}$ & $\begin{array}{c}\text { Nitrate reductase } \\
\text { activity } \\
\left(\mu \mathrm{g} \text { nitrite } \mathrm{ml}^{-1}\right)\end{array}$ & $\begin{array}{c}\text { Phosphate } \\
\text { solubilization } \\
\text { index }\end{array}$ \\
\hline POK3 & 4.80 & 15.98 & 64.46 & 2.89 \\
\hline PMK3 & 5.29 & 23.82 & 119.05 & 2.64 \\
\hline COJ4 & 3.73 & 6.94 & 52.32 & 19.18 \\
\hline MUK1 & 5.29 & 14.47 & 148.63 & 3.45 \\
\hline WHK2 & 5.29 & 31.06 & 59.15 & - \\
\hline WHN1 & 3.60 & 24.42 & 122.09 & 16.00 \\
\hline WHN2 & 4.81 & 17.79 & 131.19 & 12.96 \\
\hline
\end{tabular}

Table.2 Effect of different treatments on plant height and yield of potato under pot-house conditions at 90 DAS

\begin{tabular}{|c|l|c|c|}
\hline Treatment & DETAILS & Plant height $(\mathbf{c m})$. & Potato weight $(\mathrm{kg})$. \\
\hline T1 & CONTROL & 21 & 0.083 \\
\hline T2 & 75\%RDF (Recommended dose of fertilizer) & 23.1 & 0.126 \\
\hline T3 & RDF (Recommended dose of fertilizer) & 23.9 & 0.132 \\
\hline T4 & 75\% RDF + Mac27 (Tuber treatment) & 25.3 & 0.131 \\
\hline T5 & RDF + Mac27 (Tuber treatment) & 27.4 & 0.152 \\
\hline T6 & 75\% RDF + Mac27 (Foliar treatment) & 28.2 & 0.132 \\
\hline T7 & RDF + Mac27 (Foliar treatment) & 30.4 & 0.134 \\
\hline T8 & 75\% RDF + Bacterial isolate POK-3 spray & 32.2 & 0.156 \\
\hline T1 & RDF + Bacterial isolate POK-3 spray & 30.8 & 0.146 \\
\hline T10 & 75\% RDF + Bacterial isolate WHN-2 spray & 27.6 & 0.156 \\
\hline T11 & RDF + Bacterial isolate WHN-2 spray & 28.5 & 0.137 \\
\hline T13 & 75\% RDF + Bacterial isolate WHN-1 spray & 29.9 & 0.150 \\
\hline T14 & RDF + Bacterial isolate WHN-1 spray & 30.6 & 0.160 \\
\hline T15 & 75\% RDF + Bacterial isolate PMK-3 spray & 35.5 & 0.194 \\
\hline R16 & 75\% RDF + Bacterial isolate WHK-2 spray & 36.0 & 0.149 \\
\hline T17 & RDF + Bacterial isolate WHK-2 spray & 26.7 & 0.155 \\
\hline T18 & 75\% RDF + Bacterial isolate COJ-4 spray & 28.5 & 0.160 \\
\hline T19 & RDF + Bacterial isolate COJ-4 spray & 30.5 & 0.173 \\
\hline T20 & 75\% RDF + Bacterial isolate MUK-1 spray & 31.7 & 0.145 \\
\hline T21 & RDF + Bacterial isolate MUK-1 spray & 26.07 & 0.159 \\
\hline CD at 5\% & & 26.7 & 0.03 \\
\hline
\end{tabular}

All the bacterial isolates were characterized for IAA production (in the presence of tryptophan). All the bacterial isolates produced IAA ranging from $0.30-31.06$ $\mu \mathrm{g} / \mathrm{ml}$ respectively. The highest IAA production was observed in isolate WHK2 (31.06 $\mu \mathrm{g} / \mathrm{ml})$ followed by COK3 that produced $(29.55 \mu \mathrm{g} / \mathrm{ml}$ ) (Table 1). This is also supported by many research workers who have reported that IAA production varies with species, strains and growth conditions (Tien et al., 1979; Pathak et al., 1995). Kurepin et al., (2014) reported that inoculation of two potato cultivars with Burkholderia phytofirmans strain PsJN resulted in twofold to threefold increase in IAA and CK levels, expressed on a per plant basis. In the present piece of work, it was observed that fifteen isolates formed P- 
solubilization zone on Pikovskaya's agar medium plates and their $\mathrm{P}$ - solubilization index (P-SI) varied from 1.44-19.18. COJ4 showed maximum P-SI (Table 1). In similar way, Shahab et al., (2009) screened 28 bacteria isolated from the different soil samples of Karachi for P-solubilization and found that three strains CMG 860, CMG 854 and CMG 857 formed large haloes (20-40 $\mathrm{mm}$ within 4 days of incubation). Chandrasekeran and Mahalingam (2014) collected the rhizosphere soil samples and processed for the presence of phosphate solubilizing microorganisms. The maximum solubilization index and inorganic phosphorus production was with Bacillus sp. and Micrococcus sp.

The reduction of nitrate to nitrite is the best documented step in this system and is catalyzed by nitrate reductase enzyme. Nitrate reductase activity of all bacterial isolates was checked. All the 46 isolates showed nitrate reductase activity in nitrate broth ranging from 11.45-148.63 $\mu \mathrm{g}$ nitrite $\mathrm{ml}^{-1}$. Isolate MUK1 showed maximum nitrate reductase activity (Table 1). Similarly, Dunn et al., (1979) reported that at dissolved oxygen tension of $15 \mathrm{mmHg}(2 \mathrm{kPa})$ and below, nitrate limited continuous culture of Klebsiella K3 12 synthesized nitrate reductase (NR) and excrete ammonia. Furina et al., (2002) also tested A. chroococcum $\mathrm{C} 8$ and A. indicum 8, for the ability to reduce nitrate. Both cultures reduced nitrate to nitrite under anaerobic conditions. The nitrite amount produced by the $A$. indicum 8 was higher than the amount produced by $A$. chroococcum $\mathrm{C} 8$.

Effect of selected bacterial isolates on plant height was observed at the time of harvest being made after 90 days. Plant height ranged from $21.0-36.0 \mathrm{~cm}$ at 90 DAS. Maximum plant height was observed with foliar application of isolate PMK3 along with RDF i.e. treatment $\mathrm{T} 15(36.0 \mathrm{~cm})$ followed by foliar application of isolate COJ4 along with RDF i.e. treatment T19 $(31.7 \mathrm{~cm})$ (Table 2). Yield of potato ranged from 0.083-0.194 $\mathrm{kg} /$ pot at 90 DAS. Highest potato yield was observed in foliar application of isolate PMK3 along with RDF i.e. treatment T15 which was $0.194 \mathrm{~kg}$ followed by foliar application of isolate COJ4 along with RDF i.e. T19 (0.173 kg) (Table 2).

Similarly, Javaid (2006) also observed highest shoot length, shoot and root dry weight in the foliar spray of effective microorganisms, which was significantly greater than the rest of the treatments. Salim et al., (2013) observed that biofertilizers, micronutrients and potassium silicate treatments gave significant increase in shoot fresh and dry weights of wheat as compared to the control in both seasons.

Concerning shoot dry weight, the superiority was due to the Azotobacter and mycorrhiza treatments as compared to control and other treatments in both seasons. Singh et al., (2016) observed that emergence of tuber, number of haulms, plant height, number of leaves and dry weight of plant was significantly improved with the various treatments of organic sources of nutrients and biofertilizer. The increase in growth parameter due to large amount of vermicompost and tuber were treated with Azotobacter and phosphobacteria improved the soil structure, availability of nitrogen and phosphorus in soil, also be improved the water holding capacity, soil aeration and supply of nutrients through the use of balance fertilizers, which resulted in batter plant growth in comparison to control plots. Earlier as discussed, bacterial isolate PMK3 established well and helped in overall functioning of plant machinery. This results in the better growth and yield of potato plant, when applied aerially along with dose of fertilizer. 


\section{References}

Anonymous, 2016. Department of Agricultural Economics, Junagadh Agricultural University, Junagadh.

Banik, A., Mukhopadhaya, S. K. and Dangar, T. K. 2016. Characterization of $\mathrm{N}_{2^{-}}$ fixing plant growth promoting endophytic and epiphytic bacterial community of Indian cultivated and wild rice (Oryza spp.) genotypes. Planta., 243: 799-812

Berg, G. 2009. Plant-microbe interactions promoting plant growth and health: perspectives for controlled use of microorganisms in agriculture. Appl. Microbiol. Biotechnol., 84: 11-18.

Bockman, O. C. 1997. Fertilizers and biological nitrogen fixation as sources of plant nutrients: Perspectives for future agriculture. Plant Soil, 194: 1114.

Chandna, S. 1982. Mechanism of ammonia excretion in Azotobacter chroococcum. M. Sc. Thesis, Dept. of Microbiology, CCS HAU, Hisar.

Chandrasekeran, A. and Mahalingam, P.U. 2014. Isolation of phosphate solubilizing bacteria from sorghum bicolour rhizosphere soil inoculated with arbuscular mycorrhizae fungi (Glomus sp). Res. Biotechnol., 5: 01-05.

Chaney, A.L. and Marbach, E.P. 1962. Methods for evaluating biological nitrogen fixation (ed F.J. Bergersen) John Wiley and sons, New York. Clin.Chem. 8: 130.

Dunn, G. M., Herbertr, A. and Brown, C. M. 1978. Physiology of denitrifying bacteria from tidal mudflats in the River Tay. Physiol. Behav. Mar.Organ., pp. 135-140. Edited by D. S. McLusky and A. J. Berry. Oxford and New York: Pergamon Press.

Furina, E. K., Nikolaeva, D. A., Bonartseva, G. A., Myshkina, V. L. and L'vov, N. P.
2002. Reduction of nitrates by Azotobacter indicum and Azotobacter chroococcum Cultures. Appl.Biochem. Microbiol., 38: 558-561.

Glick, B.R., Patten, C.L., Holguin, G. and Penrose, D.M. 1999. Biochemical and Genetic Mechanisms Used by Plant Growth Promoting Bacteria. Imperial College Press, London.

Glickmann, E., Garden, L., Jaeguet, S., Hussain, S., Elasri, M., Petit, A. and Dessaux, Y. 1998. Auxin production is a common feature of most pathovars of Pseudomonas syringae. Mol. Plant Microbe Interact., 11: 156-162.

Javaid, A. 2006. Foliar application of effective microorganisms on pea as an alternative fertilizer. Agron. Sustain. Dev., 26: 257-262.

Kim, J. and Rees, D. C. 1994. Nitrogenase and biological nitrogen fixation. Biochem., 33 (2): 389-397.

Kurepin, L.V., Park, J.M., Lazarovits G. and Bernards, M.A. 2014. Burkholderia phytofirmans- Induced shoot and root growth promotion is associated with endogenous changes in plant growth hormone level. Plant Growth Regul., 75: 199-207.

Ladha, J. K. and Kundu, D. K. 1997. Effect of Growing Rice on Nitrogen Mineralization in Flooded Soil. Soil Sci. Soc. Am. J., 61(3): 839-845.

Lakshminarayana, K., Shukla, B., Sindhu, S.S., Kumari, P., Narula, N. and Sheoran, R.K. 2000. Analouge resistant mutants of A. chroococcum derepressed for nitrogenase activity and early ammonia excretion having potential as inoculants for cereal crops. Indian $J$. Exp. Biol., 38: 373-378.

Lindow, S.E. and Brandl, M.T. 2003. Microbiology of phyllosphere. Appl. Environ. Biol., 69: 1875-1883.

Narula, N., Lakshminarayana, K. and Tauro, P. 1981. Ammonia excretion by $A$. 
chroococcum. Biotechnol. Bioeng., 23: 467-470.

Pathak, D.V., Lakshmninarayana, K. and Narula, N. 1995. Analogue resistant mutants of Azotobacter chroococcum affecting growth parameters in sunflower (Helianthus annus L.) under pot culture conditions. Sci. Lett., 18: 203-206.

Salim, B.B.M., Eisa, S.S., Ibrahim, I.S., Girgis, M.G.Z. and Abdel-Rassoul, M. 2013. Effect of biofertilizers, mycorrhiza and foliar spraying of some micronutrients (Fe+ $\mathrm{Mn}+\mathrm{Zn}$ ) and potassium silicate on enhancing salt tolerance of wheat plant. Int. $J$. Environ., 2: 35-45.

Shahab, S., Ahmed, N. and Khan, N.S. 2009. Indole acetic acid production and enhanced plant growth promotion by indigenous PSBs. Afr. J. Agric. Res., 4: 1312-1316.

Singh, S., Mishra, D. P., Kumar, V. and Singh, G. 2016. Effect of Organic Sources of Nutrients and Biofertilizers on Growth and Yield of Potato. Adv. Life Sci., 5(4): 1426-1431.

Spaepen, S. and Vanderleyden, J. 2016. Auxin and Plant-Microbe Interactions. Cold Spring Harb.Persp. Biol., doi: 10.1101/cshperspect.a001438.

Tien, T.M., Gaskins, M.H. and Hubbell, D.H. 1979. Plant growth substances produced by Azospirillum brasilense and their effect on the growth of pearlmillet (Pennisetum americanum L.). Appl. Environ. Microbiol., 37: 1016-1024.

Vessey, J. K. 2003. Plant growth promoting rhizobacteria as biofertilizers. Plant Soil, 255: 571-586.

\section{How to cite this article:}

Satish Kumar, Deepika Chaudhary, Rashmi, Raman Jangra, Anju Kumari and Rakesh Kumar. 2018. Exploring Phyllosphere Bacteria for Growth Promotion and Yield of Potato (Solanum tuberosum L.). Int.J.Curr.Microbiol.App.Sci. 7(04): 1065-1071.

doi: https://doi.org/10.20546/ijcmas.2018.704.117 